\title{
Rozvoj kompetence k řešení problémů na zážitkových kurzech pro V̌̌s studenty
}

\author{
Development of problem-solving competence at experiential courses for university \\ students
}

\author{
Richard Macků
}

\begin{abstract}
Abstrakt: Příspěvek je zaměřen na prezentaci metodologického postupu a dílčích průběžných výsledků autorova komplexnějšího výzkumu úrovně kompetence k řešení problémů. Jako výsledky výzkumu jsou prezentovány jen malé změny ve schopnostech řešit prríslušný typ (teoretického) problému a dále přístup řešitelů k problémovým úlohám. Analýza výsledků výzkumu je založena na výstupech z testů a kvalitativním rozboru písemné reflexe každého respondenta a dále na výsledcích $\mathrm{z}$ doplňkových dotazníků. V první části př́spěvku jsou představeny edukační přístupy Filozofie pro děti a Výchova zážitkem.
\end{abstract}

Klíčová slova: filozofie pro děti, výchova zážitkem, kompetence k řešení problémů, problémové úlohy

\begin{abstract}
The paper is aimed at presenting the methodological procedure and partial results of the author's more complex research of a level of problem solving competence. Only small changes in the ability to solve the (theoretical) problems and an access of solvers to the tasks are presented as research results. Analysis of the results of the research is based on the outcomes from the tests and qualitative analysis of each respondent's written reflections and the results from the questionnaires. The first part presents the Philosophy for children and experiential education as educational approaches.
\end{abstract}

Keywords: philosophy for children, experiential education, problem solving competence, problem tasks

\section{1 Úvod}

Fenomén kompetence $k$ řešení problémů se postupně stal aktuálním pedagogickým tématem spolu se zaváděním rámcových (potažmo školních) vzdělávacích programu do praxe. Pojem kompetence okamžitě vyvolal vlnu emocí a vzbudil i zájem badatelů. Otázka, kterou odborná pedagogická veřejnost stále řeší, je způsob uchopení a operacionalizace pojmu kompetence. Autor tohoto příspěvku rozumí kompetencí sumu dovedností a poněkud netradičně se zabývá problematikou rozvoje kompetence $\mathrm{k}$ řešení problémů $\mathrm{u}$ vysokoškolských studentů vychovatelství, a to $\mathrm{v}$ souvislosti $\mathrm{s}$ užitím edukačních přístupů založených na výchově zážitkem a využití metod spojených s programem Filozofie pro děti. 


\section{Filozofie pro děti}

Cílem pedagogického programu Filozofie pro děti je především rozvoj samostatného myšlení. Tento př́stup vznikl v USA v 60.-70. letech 20. století na základě snahy prof. M. Lipmana ${ }^{1}$ (1969), který tak reagoval na situaci, kdy většina jeho univerzitních studentů nedokázala logicky správně argumentovat. První knihu (didaktický př́běh pro děti ve věku 11-12 let) z kurikula Filozofie pro děti, která nese název Objev Harryho Stottlemeira, napsal Lipman $\mathrm{v}$ roce 1969 . Tato kniha se stala základem celé řady př́běhů, které tvoří motivační texty pro filozofický dialog s dětmi. Metodické př́ručky ${ }^{2}$ se tento př́běh dočkal o šest let později, kdy se ukázalo, že učitelé s nefilozofickým vzděláním vyžadují pomoc s př́ípravou filozofických témat pro diskuzi. V roce 1974 byl založen Institute for the Advancement of Philosphy for Children (IAPC), jenž koordinuje aktivity související s programem Filozofie pro děti dodnes. Ideovým východiskem programu je filozofický pragmatismus - zejména myšlenky Ch. Pierce a J. Deweye. Podstatné je pragmatické přesvědčení, že pravdivost a podstatu věcí poznáváme nejlépe v dialogu. Dialogem pak v našem případě rozumíme skupinovou diskuzi, společné hledání odpovědí či řešení problému. Samostatné myšlení tedy hraje podstatnou roli, ale až v interakci s myšlením druhých, tj. ve vzájemném dialogu.

Základem filozofické „hodiny“ je čtení příběhu, který odráží nejrůznější problémy - logické, etické, související s násilím apod. Ve čtenáři tak vzbuzujeme zájem zamyslet se nad těmito problémy a klást si další otázky. Takové otázky jsou zapisovány na tabuli a jsou pak náměty pro další diskuze.

Filozofie pro děti je jedním z volitelných modulů ve studijním programu pedagogiky volného času na Teologické fakultě JU. V rámci uceleného bloku však mají možnost metody Filozofie pro děti studovat i studenti Pedagogické fakulty téže univerzity.

\section{Výchova zážitkem}

Výchovu zážitkem dnes u nás reflektuje především zážitková pedagogika. Důkazem toho je existence časopisu Gymnasion, který sice vychází jen v elektronické podobě, avšak jeho mutace Gymnos Akadémos má ambice stát se odborným recenzovaným periodikem. Přední místo zaujímá pedagogika zážitku ve studijním programu studentů Rekreologie na Fakultě tělesné kultury UP v Olomouci, nicméně setkat se s ní můžeme prakticky na všech pedagogických (a některých dalších) fakultách.

Samotný princip výchovy zážitkem je prastarý, můžeme se v této souvislosti odvolávat na řadu velikánů, kteří významněji zasáhli do dějin pedagogického myšlení (připomeňme už antický princip Kalokagathie, myšlenky J. J. Rousseaua apod.). Novodobé kořeny má tento př́stup ve dvacátém století. Na koncepční úrovni to byl zcela jistě J. Dewey (1938), který představil propracovaný edukační př́ístup, jehož hlavním znakem bylo učení se ze zkušenosti. Na úrovni metodické bychom za zakladatele výchovy zážitkem mohli považovat $K$. Hahna, který v polovině dvacátého století založil tzv. Outward Bound School, tedy školu pro vojáky britského námořnictva. Vstř́íc širému moři se na základě reálné (ale přesto částečně simulované skutečnosti) učili dovednosti přežit v extrémních podmínkách. Hahnova škola pracovala s reálnými prožitky, které napomáhaly utvářet novou, kvantitativně i kvalitativně

\footnotetext{
${ }^{1}$ Matthew Lipman, zakladatel Philosophy for Children, profesor estetiky a logiky na CU v New Yorku.

${ }^{2}$ Ke každému $\mathrm{z}$ př́íběhů existuje metodická příručka, která pomáhá zorientovat se $\mathrm{v}$ hlavních myšlenkách príběhu, nabízí plány diskuze pro jejich nasměrování či prohloubení, ale i cvičení pro oživení a lepší pochopení diskutovaného.
} 
větší zkušenost. Dnes nese označení Outward Bound organizace, jež zastřešuje jednotlivé národní školy, které využívají záměrného navozování zážitků k rozvoji osobnosti i skupin.

Do teoretických konceptů zážitkového učení vstupují později úvahy $D$. Kolba (1984), který především sumarizoval myšlenky J. Deweyho a K. Lewina. Od vydání jeho knihy Experiential learning se mnohem důrazněji rozpracovává fenomén reflexe; zatímco v prvních desetiletích výchovy zážitkem šlo především o samotné prožitky, dnes se za nejdůležitější fázi v celém cyklu považuje reflexe. Závěrem tohoto historicko-přehledového exkurzu je třeba připomenout, že principy výchovy zážitkem uplatňují i další pedagogové - aniž by je tak nazývali. Za všechny jmenujme např. dnes populárního brazilského edukátora P. Freire.

Zážitková (někdy též zkušenostní) edukace je tedy postavena na záměrném navozování prožitků, které mají napomoci utvářet novou (modifikovat stávající) zkušenost tak, abychom následně byli schopni v podobných situacích jednat efektivněji. V českém prostředí se specifickým prostředkem k navozování prožitku stala během uplynulých desítek let hra.

\section{Výzkum rozvoje kompetence $k$ řešení problémů}

Autor příspěvku považuje výše popsané př́stupy za komplementární; kombinaci metod obou př́stupů by bylo možné považovat za vhodnou cestu inovace např. volnočasových edukačních aktivit. Abychom tento předpoklad mohli konstatovat s jistotou, je třeba uskutečnit šetření $\mathrm{s}$ cílem zjistit úroveň kompetence $\mathrm{k}$ řešení problémů před a po absolvování př́íslušných kurzů (tedy zážitkového a Filozofie pro děti). Zajímá nás kvantitativní úroveň kompetence (kolik problémových úloh různých typů řešitel správně vyřeší) a kvalitativní úroveň, která vyjadřuje způsob uchopení a řešení problému.

Pro výzkumné účely se obecně přijímané, široké, vymezení kompetence jeví jako velice komplikovaně použitelné. Pro potřeby našeho výzkumu uvažujeme „pouze“ o dovednostech řešit problémy a $\mathrm{z}$ jejich změny chceme uvažovat o přesahu $\mathrm{k}$ modifikaci celé kompetence. Opravňuje nás k tomu pojetí dovednosti, které předkládá Švec (1998): „Dovednost je způsobilost subjektu (sycená schopnostmi, zkušenostmi, stylem učení, motivy aj.). “ Takové vymezení umožňuje širší chápání fenoménu dovednosti, které může obsahovat kromě znalostní i onu postojově-hodnotovou složku kompetence.

Pokud pojednáváme o dovednostech řešit problémy, je třeba si definovat pojem problém. Jako problém označme tedy jakoukoliv situaci, která se v aktuální okamžik liší od cílového stavu. K odlišení jednotlivých typů problémů nám může pomoci tzv. problémové kontinuum (srov. Getzels \& Csikszentmihalyi, 1967), které později doplnila C. June Maker z University of Arizona (Maker, 2004, s. 341-413; obrázek 1). 


\begin{tabular}{|c|c|c|c|c|c|c|}
\hline \multirow{2}{*}{ typ } & \multicolumn{2}{|c|}{ Problém } & \multicolumn{2}{|c|}{ Metoda } & \multicolumn{2}{|c|}{ Rešení } \\
\hline & Předkladatel & Řešitel & Předkladatel & Řešitel & Předkladatel & Řešitel \\
\hline I. & $\checkmark$ & $\checkmark$ & v & $\checkmark$ & $\checkmark$ & $x$ \\
\hline II. & $\checkmark$ & $\checkmark$ & $\checkmark$ & $\mathbf{x}$ & $\checkmark$ & $\mathbf{x}$ \\
\hline IIII. & $\checkmark$ & $\checkmark$ & $\ldots$ & $\mathrm{x}$ & $\ldots$ & $\mathrm{x}$ \\
\hline IV. & 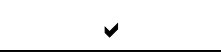 & $r$ & $\mathbf{x}$ & $\mathrm{x}$ & $\mathbf{x}$ & $\mathbf{x}$ \\
\hline V. & $\mathbf{x}$ & $\mathbf{x}$ & $\mathbf{x}$ & $\mathbf{x}$ & $\mathbf{x}$ & $\mathbf{x}$ \\
\hline
\end{tabular}

Obrázek 1. Problémové kontinuum.

Tato matice nám umožňuje vymezit několik typů problémů na základě jejich kvalitativní odlišnosti (nikoliv obtížnosti). Zatímco první typ představuje vysoce strukturované problémy, které je možné řešit pouze jednou konkrétní cestou a dojit $\mathrm{k}$ jednomu správnému závěru, pátý typ je zcela nestrukturován a $s$ otevřeným řešením (popř. několika řešeními), ke kterému je možné dojít zpravidla za pomoci různých metod.

\section{Průběžné a dílčí výsledky z předvýzkumu}

Předvýzkum byl koncipován jako testování pomocí testových dotazníků. Účastníci dvou zážitkových kurzů $\mathrm{z}$ řad studentů pedagogiky volného času $(\mathrm{n}=2 \times 25)$ řešili bezprostředně před kurzem 20 problémových úloh, z nichž 10 mělo povahu problémů teoretických a 10 praktických (vždy 2 problémové úlohy od každého typu). Teoretické úlohy řešili účastníci samostatně, praktické ve skupině 5 dalších řešitelů. Stejným procesem testování prošli respondenti v závěru kurzu - testové úlohy nebyly shodné, ale analogické (př́slušnost k typu, obsahová podobnost). Kromě samotného řešení úlohy, pro které byl vyčleněn časový interval 5 minut, byl v záznamových arších vymezen prostor pro reflexi řešení dané úlohy (4 minuty). Tato reflexe, spolu s dalším doplňujícím dotazníkem, byla koncipována jako klíč k odhalení kvalitativní složky kompetence k řešení problémů. Níže (tabulka 1) představujeme výsledky úspěšnosti $v$ řešení problémových úloh a dílčí výsledky $\mathrm{z}$ vyhodnocení doplňujícího dotazníku. Zatím tedy nejsou zahrnuta data z reflexe, z hlediska práce výzkumníka však lze upozornit na některé zásadní poznatky (týkající se reflexe řešení úloh), které budou rozhodující při zpřesňování metodologie v dalších fázích výzkumu:

- U velké části respondentů nastal problém s chápáním a zaměňováním některých termínů - např. fáze, kritérium, alternativní řešení, role.

- Při popisu fází řešení docházelo zpravidla $\mathrm{k}$ uvedení dvou fází - zadání a řešení; při pokusu identifikovat (pro řešení problému) podstatné role ve skupině byla často zvažována jen jedna fáze.

- V př́ípadě pobídky $\mathrm{k}$ zařazení problémových úloh do širší skupiny podobných problémů docházelo velmi často rozdělení dle didaktických hledisek (tzn. z hlediska vnější formy aktivity, nikoli z hlediska vnitřní podstaty problému).

- Výjimečný nebyl ani výskyt odporujících si výpovědi (např.: ,žádné alternativy mě nenapadají“"vs. „možná by bylo lepší'“)

- Velice znepokojující byla i pravopisná a grafologická stránka vypracování. 
Tabulka 1

Kvantitativni hledisko: řešení problémových úloh

\begin{tabular}{|l|c|c|}
\hline & \multicolumn{2}{|c|}{ Průměrná procentuální úspěšnost } \\
\hline v řešení všech úloh & PRE 56,8 \% & POST 59,9 \% \\
\hline v řešení praktických úloh & PRE 58,6 \% & POST 58,9 \% \\
\hline v řešení teoretických úloh & PRE 54,9\% & POST 60,8 \% \\
\hline
\end{tabular}

Největší nárůst byl zaznamenán u úloh typu I, IV a V (12, 16 a $11 \%)$, pokles u typu III. Je však třeba důrazně upozornit, že svou roli při řešení hrála rozdílná obtížnost úloh, která (v př́padě některých úloh) ovlivnila výsledky. ${ }^{3}$ Výše uvedené výsledky jsou procentním vyjádřením úspěšnosti řešení všech respondentů a ve všech úlohách (tzn. 100\% úspěšnost by vyžadovala zisk 3 bodů všech respondentů ve všech úlohách).

Stručně seznámíme také s dílčími výsledky analýzy doplňkového dotazníku, který byl sestaven na základě kognitivně-psychologických teorií způsobu řešení problémů. Respondenti se v dotazníku přikláněli vždy ke konkrétní technice, která odpovídá širšímu ucelenému př́stupu k problémům. Na základě toho se podařilo sestavit pracovní verzi charakteristiky typického řešitele v pojednávané skupině respondentů:

Řeši jako člen skupiny, v řešení je systematický, nespoléhá na náhlý vhled, proces řešení rozděluje do fází, je ochoten přijímat i produkovat, vice použivá postupy ověrené predchozí zkušeností; v řešení je však otevřený novým př́stupưm. Skupina naopak není koherentní ve způsobu uchopení problému.

\section{Závěr}

Představili jsme dílčí výsledky z předvýzkumu, které nám spíše ukazují metodologické nesrovnalosti $v$ celém šetření. V této fázi není možné popsané výsledky jednoznačně interpretovat. Statistické analýzy nám pomohou odhalit, zda zjištěný výsledek je pro zodpovězení naší otázky významný, nicméně na výsledcích se do značné míry odráží více obtížnost jednotlivých úloh, než jejich kvalitativní odlišnost. S jistotou tedy nelze konstatovat, zda uskutečněné kurzy skutečně napomohly zvýšení (byt' malému) dovedností řešit teoreticky pojaté problémové úlohy.

Kromě revize úloh bude třeba pro další části výzkumu rovněž snížit celkový čas testování, přestrukturovat doplňující dotazník a reagovat na zmíněné technické nedostatky (např. zpřesnění pojmů v zadání testů).

\footnotetext{
${ }^{3}$ Hodnocení úspěšnosti v plnění úloh bylo několikastupňové s užitím bodů: 0 - nesplněno / nezapsáno řešení, postup či jiná informace, kterou by výzkumník mohl považovat za částečné řešení; 1 - špatné řešení, avšak zcela správný postup / správné řešení, špatný postup, u typu 5 pouhá identifikace problému; 2 - správný postup a správné, ale neúplné řešení / správné a úplné řešení bez možnosti ověření postupu (je-li vyžadováno)/ částečně správné řešení (s chybnými prvky), u typu 5 identifikace problému + prezentace pasivního řešení; 3 - zcela správné řešení, u typu 5 identifikace problému + prezentace aktivního řešení.
} 


\section{Literatura}

Dewey, J. (1938). Experience and education. New York: Macmillan Co.

Getzels, J. W., \& Csikszentmihalyi M. (1967). Scientific creativity. Science Journal, 3(9), 80-84.

Lipman, M. (1974). Harry Stottlemeier's discovery. Upper Montclair, NJ: The Institute for the Advancement of Philosophy for Children, Montclair State University.

Kolb, D. A. (1984). Experiential learning: Experience as the source of learning and development. New Jersey: Prentice Hall.

Maker, C. J. (2004). Creativity and multiple intelligences: The discover project and research. In L. Sing (Ed.), Creativity: When East meets West (pp. 341-413). New York: WSPC.

Švec, V. (1998). Klićové dovednosti ve vyučování a výcviku. Brno: PdF MU v Brně.

\section{Kontakt}

Mgr. Richard Macků, DiS.

Jihočeská univerzita

TF, Katedra pedagogiky,

Kněžská 8, 37001 České Budějovice

e-mail: mackur@tf.jcu.cz

\section{Bibliografické údaje}

Macků, R. (2011). Rozvoj kompetence k řešení problémů na zážitkových kurzech pro VŠ studenty. In T. Janík, P. Knecht, \& S. Šebestová (Eds.), Smišený design v pedagogickém výzkumu: Sborník př́spěvků z 19. výroční konference České asociace pedagogického výzkumu (s. 362-367). Brno: Masarykova univerzita.

Dostupné z: http://www.ped.muni.cz/capv2011/sbornikprispevku/macku.pdf

doi: 10.5817/PdF.P210-CAPV-2012-36 